\title{
RESEARCH ACTIVITIES IN THE SUB-ANTARCTIC
}

\author{
by Yves Frenot
}

(with two text-figures and one table)

\begin{abstract}
Frenot, Y. 2007 (23:xi): Research activities in the sub-Antarctic. Papers and Proceedings of the Royal Society of Tasmania 141(1): 111-114. https://doi.org/10.26749/rstpp.141.1.111 ISSN 0080-4703. UMR 6553 CNRS-Université de Rennes I and French Polar Institute (IPEV), Station Biologique, F-35380 Paimpont, France.
\end{abstract}

Current scientific activity in the sub-Antarctic islands is assessed in the context of past achievements and potential future issues. Brief mention is made of the scientific expeditions of the nineteenth and twentieth centuries. A survey of international bibliographic databases revealed the dominance of research in the life sciences, reflecting the unique characteristics of sub-Antarctic ecosystems. Research and monitoring in geosciences are also important components of scientific activities in these islands. Climate change and non-native species are two issues which dominate current and probably future studies in the sub-Antarctic.

Key Words: sub-Antarctic, research, science, bibliography, scientific expeditions.

\section{INTRODUCTION}

Although the surface area of the sub-Antarctic islands may appear negligible, they are fascinating locations for research. Much of the interest scientists show in these remote spots centres on their ecological characteristics.

First, they are geographically isolated: each island is several thousand kilometres from the nearest continent. Their relatively late discovery, at the end of the eighteenth century or later, kept the region free of human influence (and of research activities) until very recently.

While their climatic conditions vary slightly with their positions relative to the Polar Front, these islands are characterised by a hyperoceanic climate, with, for example, cool temperatures close to $0^{\circ} \mathrm{C}$ throughout the year, high precipitation and strong winds (see Convey 2006). The climate is not as extreme as in Antarctica, but it constitutes a major constraint for the development of many organisms which in the sub-Antarctic are at the limit of their distribution.

As a consequence of the islands' isolation and climatic conditions, biodiversity, which is relatively high in marine ecosystems, is very low in terrestrial habitats. This is illustrated, for example, by the low number of native plant species. The rate of endemism, however, is relatively high and morphological adaptations such as apterism of insects are common. The sub-Antarctic ecosystems are also characterised by a significant level of nutrient transfer between the terrestrial and marine environments via seabirds and seals.

Indigenous species such as herbivorous and carnivorous land mammals that play a major role in continental ecosystems are absent from the natural sub-Antarctic terrestrial ecosystems. Combined with the very high primary production of many plant communities, this lack has a significant effect on ecosystem structure and function. Predators are rare (there are some predatory spiders and insects) and energy flow is controlled by detritivores such as fungi and bacteria or saprophagous invertebrates, rather than by herbivores.

These characteristics explain why the sub-Antarctic terrestrial ecosystems are relatively simple compared with those in more temperate regions, and why they can be sensitive to environmental changes. Because they also provide breeding habitats for a huge number of marine birds and mammals, the sub-Antarctic islands constitute ideal sites for ecological research.

The aim of this paper is to present a brief overview of scientific research in the sub-Antarctic in the context of past achievements and potential future issues. The objective is not to provide a detailed assessment of the activities carried out in each island, but rather to stress some common features, mainly through the analysis of the sum of publications produced about this region.

This overview concentrates mainly on the narrow belt between the Subtropical Convergence and the Polar Front. Only islands close to the oceanic Polar Frontal Zone, where cold Antarctic waters sink below a warmer surface layer, are considered, namely South Georgia, Marion and Prince Edward, Crozet, Kerguelen, Heard, McDonald, and Macquarie islands.

\section{THE PRE-1950 PERIOD}

The sub-Antarctic islands were discovered relatively late, most of them at the end of the eighteenth century, by sailors such as Cook and Kerguelen who searched for Terra Australis Incognita. Macquarie Island was discovered later, in 1810, and Heard Island only in 1853, after the discovery of the Antarctic continent. Very soon after their discovery, human visits focused almost exclusively on economic exploitation of wildlife: fur seal skins, elephant seal oil and penguin oil.

Although the Challenger Expedition (1872-76) was designed to explore the depths of the sea, it provided the first opportunity for scientists to visit a number of subAntarctic islands: Prince Edward, Kerguelen and Heard islands. The shoreline of the McDonald islands was surveyed on that occasion and geological and botanical samples were collected on Heard Island. In 1874, Îles Kerguelen were also a base for the observation of the Transit of Venus by the Gazelle Expedition.

The first scientific expedition to South Georgia was the German International Polar Year Expedition of 1882-83. Eleven men spent a year at Moltke Harbour in Royal Bay to implement a varied scientific program and to observe the Transit of Venus. A biological survey was carried out by the Swedish South Polar Expedition in 1902. 
During the German Gauss Expedition (1901-03) valuable investigations were conducted in geology, geography, earthmagnetism, oceanography, meteorology and biology. A base station was established at Observatory Bay on Îles Kerguelen in 1901 and the expedition also visited the Îles Crozet.

The German Deutschland Expedition visited South Georgia three times in 1911 and 1912 and made the first real survey of the interior of the island. Over the same period, the Australasian Antarctic Expedition (AAE, 1911-14) established the first meteorological station at Macquarie Island, and carried out the first significant biological and geological surveys there.

After the end of the Second World War, several stations were established, some of them permanently, others temporarily (table 1).

\section{THE PERIOD 1950-75}

Permanent stations were established on most of the subAntarctic islands during this period. After the end of the Second World War, the objectives of the governments were obviously to affirm their sovereignty on these islands.

Control of Heard Island, for example, was disputed by the United States and the sovereignty of Heard and McDonald islands was transferred from Britain to Australia as soon as the Atlas Cove station opened (Green 2006). In 1960, Madagascar became independent and claimed the French sub-Antarctic islands located in the Southern Indian Ocean (Crozet, Kerguelen). While Port-aux-Français Station had, by then, already been continuously occupied for nine years on Kerguelen, the necessity to affirm French sovereignty on Îles Crozet was probably one of the main reasons for the establishment of the Alfred Faure station at Possession Island, Crozet archipelago.

The second purpose of the establishment of permanent stations in this region was to set up meteorological observatories. Despite the development of aviation, travelling by sea remained the main means of cargo and passenger transport between the continents. The establishment of meteorological stations contributed to increased safety in the "Roaring Forties". South Africa, for example, set about annexing Marion and Prince Edward islands in December 1947 and a meteorological station was set up in 1948 (Prince Edward Islands Environmental Management Plan 2005).

Generally, few coordinated research programs were undertaken in the first years of occupation. The major exception was the first scheduled research visit to both Marion and Prince Edward islands in 1965: the South African Biological and Geological Expedition was initiated and led by Edward M. van Zinderen Bakker Sr: The extensive results published in 1971 marked the start of a new era in research activities in the sub-Antarctic.

\section{FROM THE MID-1970S TO THE PRESENT}

In order to assess the diversity of recent scientific activities in the sub-Antarctic islands, I have analysed publications stored in several databases available through the web. These are: Science dr Technology Current Contents Search produced by Thomson Scientific - Institute for Scientific Information; Inspec produced by the Institute of Electrical Engineers; Medline produced by U.S. National Library of Medicine;
TABLE 1

The sub-Antarctic permanent stations

\begin{tabular}{|c|c|c|}
\hline $\begin{array}{l}\text { Island (nationality of } \\
\text { station) }\end{array}$ & $\begin{array}{l}\text { Year of permanent sta- } \\
\text { tion establishment }\end{array}$ & $\begin{array}{c}\text { Average } \\
\text { number of } \\
\text { people in } \\
\text { winter }\end{array}$ \\
\hline Marion (South Africa) & 1948 & 25 \\
\hline Macquarie (Australia) & $1948^{\circ}$ & 20 \\
\hline Heard (Australia) & 1947 (closed in 1955) & \\
\hline South Georgia (UK) & 1950 & 5 \\
\hline Kerguelen (France) & 1951 & 60 \\
\hline Crozet (France) & 1962 & 25 \\
\hline
\end{tabular}

International Science Database produced by INIST-CNRS; and Pascal produced by INIST-CNRS.

The search for relevant publications was carried out using the Webspir multibase search tool produced by INIST-CNRS (http://bibliosciences.inist.fr/ access submitted to subscription). The search was restricted to the period 1975-2006. The character string "sub-antarc*" or "subantarc" in title, key words or abstract was searched. Another search was performed using the name of one of the islands or island groups considered here (South Georgia, Marion, Prince Edward, Crozet, Kerguelen, Heard, McDonald, and Macquarie islands). Results were checked to eliminate duplicated or inappropriate references (for example, publications related to Marion Island in the Arctic). Each reference was placed into one of seven arbitrary scientific fields, namely: terrestrial ecology; marine ecology; geosciences; human biology and medicine; human impact research; environmental management; and taxonomy, systematics and biogeography.

The search retrieved about 3310 scientific references dealing with the sub-Antarctic region as defined here. Some deal exclusively with marine science and reported on oceanographic expeditions which took place in the sub-Antarctic region. These data have been discarded and a total of 2716 references, restricted to the sub-Antarctic islands themselves or their coastal and near-shore marine environment, were examined.

This total underestimates the high productivity of the scientists working in this area: most of the studies carried out at the beginning of the period under consideration were published in reports, journals or books not indexed in the analysed databases. For example, the numerous papers included in the report of the Marion and Prince Edward Islands Expedition (1965) are not present in the list. Similarly, the important works published in the British Antarctic Survey Bulletin are absent. However, it may be assumed that this bias is the same for all islands and this list of references is likely to be a reflection of the importance of each field of activity.

The distribution pattern of scientific fields is shown in figure 1. Most studies carried out in the sub-Antarctic are related to terrestrial ecology. More than 100 publications per year have been produced in this domain during the last 10 years. By comparison, marine ecology is less studied but remains one of the main scientific issues. As a result, $67 \%$ of the studies deal with ecosystem functioning, population dynamics, adaptation, ecophysiology or genetics.

Among the 1157 references related to terrestrial ecology, most concern marine vertebrates, birds and seals, followed 


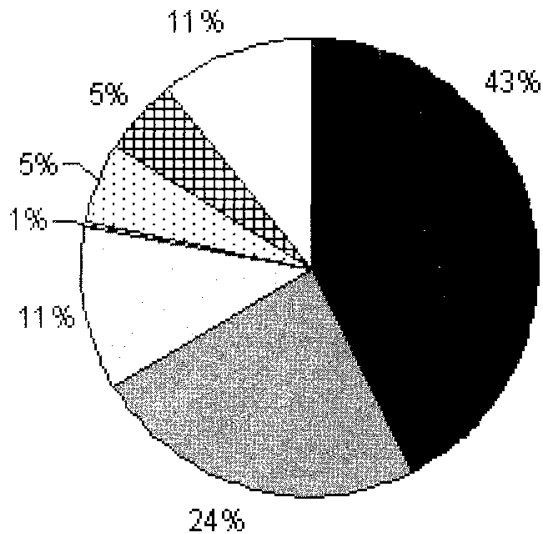

$24 \%$

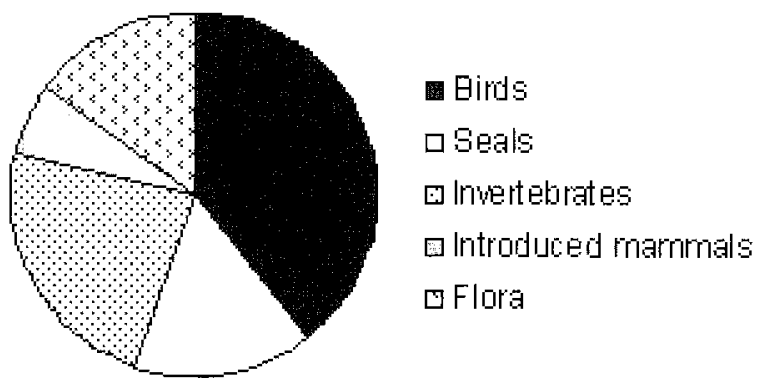

FIG. 2-Distribution of the publications in terrestrial ecology according to their main topic.

by invertebrate fauna and flora (fig. 2). In addition, a significant number of studies have been carried out on the introduced mammals.

Two "new" scientific fields are emerging: publications on climate change appeared for the first time at the end of the 1980 s, and account for $10 \%$ of the publications in 2003-06. Similarly, the number of papers related to alien species and their impact on the native communities or ecosystems markedly increased in the 1990s and accounts now for about $10 \%$ of the publications. These changes probably result from the influence of two successive SCAR programs, BIOTAS (Biological Investigations of Terrestrial Antarctic Systems) and RiSCC (Regional Sensitivity to Climate Change in Antarctic Terrestrial Ecosystems), which initiated and coordinated most of the research in the subAntarctic terrestrial ecology.

Research in taxonomy and biogeography is also an important component of the scientific activity (fig. 1). A total of 221 references ( $11 \%$ of the total publications) was identified in taxonomy and systematics, 144 concerning terrestrial biota and 77 concerning marine biota. A total of 105 publications relates to the biogeography and history of colonisation of sub-Antarctic islands.

Geosciences account for about $11 \%$ of the research activity, mainly in the field of geology and, to a lesser extent, glaciology, seismology, geomagnetism, ionosphere and atmosphere chemistry. It is interesting that no publications are directly linked to meteorological observations, although climatic data are available through international databases or publications on climate change.

More than $5 \%$ of the publications concern environmental management: conservation issues $(2.7 \%)$, control or eradication of species (1.2\%) and management policy (1.6\%).
Among this last category are several articles on cultural heritage and conservation of historic remains.

Finally, $1 \%$ of the publications relate to human biology and medicine. They mainly concern human behaviour such as the coping strategies used by expeditioners during overwintering.

The bibliographic survey emphasises the dominance of research in the life sciences. The oldest but still important area concerns taxonomy and biogeography. The high rate of endemism is a very interesting issue to biologists who sometimes call these islands the "sub-Antarctic Galapagos". Sub-Antarctic data also have been used extensively in the discussions on insularity theory (see e.g., Vitousek et al. 1995). Today, the development of molecular biology offers another avenue of taxonomic investigation.

Another characteristic of research in the sub-Antarctic is the regular support by national agencies of long-term studies, support which is probably stronger than elsewhere in the world. For example, data on bird populations in the French sub-Antarctic islands have been collected for more than 40 years (Weimerskirch et al. 2003). These long-term data are extremely useful in understanding the impact of environmental changes on these animals. For example, the decline in numbers of Wandering Albatrosses was probably related to the impact of fisheries around Kerguelen, Marion and Crozet islands (Weimerskirch et al. 1997). These results led to changes in fishing techniques and the populations are now recovering. These data can also reveal the susceptibility of species to climate change or the impoverishment of food resources.

The impact of climate change on terrestrial and marine sub-Antarctic ecosystems has become a significant issue. Temperature increases, amongst the most rapid in the world, are well documented in the sub-Antarctic, with reports from several locations of increases in annual air temperatures of at least $1^{\circ} \mathrm{C}$ over the last $30-50$ years. Decreasing precipitation has been reported at Marion and Kerguelen islands since the early 1970s. Most of the subAntarctic glaciers at Heard Island, Îles Kerguelen and South Georgia are currently retreating. The changes have strong impacts on terrestrial ecosystems, such as decline in water availability and desiccation of the native vegetation in some locations (Convey 2006).

Simultaneously, introduction of alien species is probably the second most important threat to sub-Antarctic ecosystems and many studies on this issue have been initiated in recent years (e.g., Frenot et al. 2005). The current warming may have important biological consequences. It could be 
responsible for the success or failure of the establishment of new species, particularly ectothermic organisms unable to regulate their own temperature and living at temperatures close to their threshold for development.

Several eradication or control programs have been attempted, some of them successfully. For example at Marion Island, cats, which were responsible for the near local extinction of some bird species, were successively trapped, subjected to a viral disease, poisoned and shot during the 1980s. The last time a cat was seen on the island was in 1991 (Bloomer \& Bester 1992). It is now believed that complete eradication of feral cats on Marion Island has been achieved and burrowing petrels, which were severely affected by the cats, have now shown signs of recovery.

Although there is no doubt that the life sciences are the major component of scientific activities in the sub-Antarctic, the present bibliographic survey probably underestimates activity in the geosciences. Several geological studies and maps are now available. These islands are geologically interesting as most of them are true oceanic islands, with no relation to former continents (e.g., Quilty 2006). They are generally associated with marine ridges or zones of contact between large plates and they provide useful information on the nature of deep materials from the Earth's mantle.

Finally, one of the most underestimated areas is probably the research associated with observatory and monitoring activities. The sub-Antarctic islands fill a gap in a vast expanse of ocean by providing sites where extremely rare and valuable data of global interest can be monitored. In this context, meteorology was usually one of the first scientific activities implemented in the sub-Antarctic islands and the stations are crucial for understanding the global climate. Similarly, the participation of the sub-Antarctic observatories in different fields of earth science such as seismology, geomagnetism, and atmospheric chemistry as part of global networks is crucial to increasing the quality of modelling and our understanding of processes at a global level.

\section{CONCLUSION}

One of the main conclusions of this study is that there is no "sub-Antarctic scientific research" but research carried out in the sub-Antarctic. However, the scientific activity in this region is clearly related to the particular characteristics of the islands and their ecosystems.

Scientific collaborations between researchers on various sub-Antarctic islands has increased significantly during the past decade. For example, the former RiSCC program, supported by SCAR, allowed the development of collective studies to analyse the impact of climate change on the biodiversity and ecosystems of the Antarctic and subAntarctic regions. In 2004, expeditions were conducted on Heard, Kerguelen and Marion islands to make simultaneous observations and measurements on common plant and invertebrate species, using exactly the same protocols.
In the near future, the main scientific issues in the subAntarctic clearly will be related to climate change, non-native species, and human impacts on biodiversity and ecosystem functioning. From these points of view, the sub-Antarctic islands will provide important pointers to changes that could occur in more southerly areas, namely in the Antarctic Peninsula. They give key opportunities to improve our understanding of the consequences of climate changes on terrestrial habitats and, more generally, to improve our knowledge of ecosystem functioning.

\section{ACKNOWLEDGEMENTS}

Thanks are due to the organisers of the International Forum on the Sub-Antarctic who offered the opportunity to present this synthesis at Hobart in July 2006. Dr Patricia Selkirk is thanked for her valuable comments and contribution for improving the initial version of the manuscript.

\section{REFERENCES}

Bloomer, J.P. \& Bester, M.N. 1992: Control of feral cats on Sub-Antarctic Marion-Island, Indian Ocean. Biological Conservation 60: $211-219$.

Convey, P. 2006: Antarctic climate change and its influences on terrestrial ecosystems. In Bergstrom, D.M., Convey, P. \& Huiskes, A.H.L. (eds): Trends in Antarctic Terrestrial and Limnetic Ecosystems. Springer, Dortrecht: 253-272.

Frenot, Y., Chown, S.L., Whinam, J., Selkirk, P.M., Convey, P, Skotnicki, M. \& Bergstrom, D.M. 2005: Biological invasions in the Antarctic: extent, impacts and implications. Biological Reviews 80: 45-72.

Green, K. 2006: Sovereignty, science and twentieth century sealing. In Green, K. \& Woehler, E. (eds): Heard Island, Southern Ocean sentinel. Surrey Beatty \& Sons, Chipping Norton, Australia: 196-201.

Prince Edward Islands Environmental Management Plan 2005: DST-NRF Centre of Excellence for Invasion Biology, Stellenbosh, South Africa.

Quilty, P.G. 2006: Heard Island and the McDonald islands: built on the Kerguelen Plateau foundation. In Green, K. \& Woehler, E. (eds): Heard Island, Southern Ocean Sentinel. Surrey Beatty \& Sons, Chipping Norton, Australia: I-9.

Vitousek, P.M., Loope, L.L. \& Adsersen, H. 1995: Islands. Biological Diversity and Ecosystem Function. Ecological Studies 115. Springer, Berlin: $238 \mathrm{pp}$.

Weimerskirch, H., Brothers, N. \& Jouventin, P. 1997: Population dynamics of Wandering Albatross Diomedea exulans and Amsterdam albatross D. amsterdamensis in the Indian Ocean and their relationships with long-line fisheries: Conservation implications. Biological Conservation 79: 257-270.

Weimerskirch, H., Inchausti, P., Guinet, C. \& Barbraud, C. 2003: Trends in bird and seal populations as indicators of a system shift in the Southern Ocean. Antarctic Science 15: 249-256.

(accepted 24 September 2007) 